\title{
THE INFLUENCE OF STREET TREES ON URBAN MICROCLIMATE
}

\author{
Angeline Martini ${ }^{1 *}$, Daniela Biondi² ${ }^{2}$ Antonio Carlos Batista ${ }^{3}$ \\ ${ }^{1 *}$ Universidade Federal de Viçosa, Departamento de Engenharia Florestal, Viçosa, Minas Gerais, Brasil - martini@ufv.br \\ ${ }^{2}$ Universidade Federal do Paraná, Departamento de Engenharia Florestal, Curitiba, Paraná, Brasil - dbiondi@ufpr.br \\ ${ }^{3}$ Universidade Federal do Paraná, Departamento de Engenharia Florestal, Curitiba, Paraná, Brasil - batistaufpr@ufpr.br
}

Received for publication on: 07/10/2018 - Accepted for publication on: 15/03/2019

\begin{abstract}
Resumo
Influência das árvores de rua sobre o microclima urbano. A melhoria do microclima é frequentemente apontada como um dos benefícios gerados pela arborização urbana. No entanto, há poucos estudos que abordam quantitativamente esse efeito. O objetivo desse trabalho foi comparar o microclima de ruas com e sem arborização. Para isto foram selecionadas três amostras, contendo um trecho de rua com e outro sem arborização, sendo que as ruas arborizadas eram compostas por diferentes espécies. Os dados de temperatura do ar, umidade relativa do ar e velocidade do vento foram medidos usando uma miniestação meteorológica automática, marca Kestrel ${ }^{\circledR}$, instalada na rua arborizada e a outra na rua sem arborização. A coleta desses dados foi das 9 às 15 horas, com intervalo de monitoramento de 1 minuto, repetida nas quatro estações do ano, com início no inverno de 2011. As análises comparativas foram feitas usando-se o teste t de Student (99\%). Os resultados indicaram que a temperatura do ar em uma rua arborizada foi em média $1,7{ }^{\circ} \mathrm{C}$ menor do que uma rua sem arborização, a umidade relativa foi $6,9 \%$ maior e a velocidade do vento $0,04 \mathrm{~m} / \mathrm{s}$ menor. Para a temperatura, não houve diferença estatística entre a rua arborizada com ipê e a rua sem arborização nas estações do inverno e primavera. No verão, para a velocidade do vento, não houve diferença entre a rua sem arborização e a arborizada com ipê e tipuana. Conclui-se que a arborização de ruas proporciona microclima mais ameno, sendo que essa influencia foi estatisticamente significativa.

Palavras-chave: arborização urbana, ruas arborizadas, microclima.
\end{abstract}

\begin{abstract}
The microclimatic improvement is often cited as one of the benefits generated by urban trees, however, there are few studies which quantitatively address this effect. The aim of this paper was to compare the microclimate of streets with and without trees. Therefore, three samples containing a stretch of street with and without trees were selected, with the street with trees being composed of different species. The temperature, relative humidity and wind speed data were measured by automatic Kestrel ${ }^{\circledR}$ meteorological ministations installed on the street with trees and another in the street without trees. The data collection period was from 9 AM to 3 PM, and the monitoring interval was every 1 minute during all four seasons starting in the winter of 2011. The comparative analyses were done using the Student's t-test (99\%). The results indicated that the air temperature in a street with trees was on average $1.7{ }^{\circ} \mathrm{C}$ lower than a street without trees, the relative humidity was $6.9 \%$ higher and the wind speed was $0.04 \mathrm{~m} / \mathrm{s}$ lower. There was no statistical difference for temperature between the street with "ipê" in the winter and spring. There was no difference for wind speed in the summer between the street with other trees and the street with "ipê" and "tipuana". It was concluded that street trees provide a pleasant microclimate, and this influence was statistically significant.

Keywords: urban forestry, street with afforestation, microclimate.
\end{abstract}

\section{INTRODUCTION}

The development of urban spaces without proper planning attributes unhealthy characteristics to a city, mainly due to anthropic actions and their effects (MARTINS et al., 2011). In view of the impacts arising from the urbanization process, one of the ways to promote improvement in the quality of life of a population in cities is to carry out correct planning and planting of trees, whether in public or private areas (BOBROWSKI; BIONDI, 2012).

It is unquestionable that trees play a vital role in the well-being of urban communities. Their unique ability to control many of the adverse effects of the urban environment contributes to a significant improvement in the quality of life (VOLPE-FILIK et al., 2007). In addition to promoting quality of life, vegetation can favor the livability of cities, improving the landscape, environmental quality and people's own health (JIM et al., 2015).

The various functions that trees play in cities, their value, costs, benefits and the very diverse influence that they have in urban areas have been widely discussed (DONOVAN; BUTRY, 2010). Thus, cities around the world have promoted urban forests in recent decades, being supported by scientific theory and empirical evidence as a way of keeping their citizens healthy, as well as improving environmental and economic conditions (JIANG et al., 2015). 
Many studies point to the use of vegetation as a mitigating factor for climatic problems occurring in cities. For Chang and Li (2014), the urban forest can be used as a measure to cool portions of urban areas, reducing the intensity and magnitude of the negative impacts of heat islands. Yu and Hien (2006) emphasize that when the vegetation is well distributed, the energy balance of the whole city can be modified by adding more evaporative surfaces, more absorbed radiation can be dissipated in the form of latent heat and the urban temperature can be reduced. In this context, Huang et al. (2008) stated that studies on the urban climate should be stimulated to assist in the various decisions of environmental planning and rehabilitation of urban areas.

The positive advances in the microclimate are quite significant when there is a project for afforestation of an area, since in addition to performing the mechanism for filtering atmospheric gases, the presence of tree species can also be responsible for the social well-being of the population (BENATTI et al., 2012). Thus, assuming the hypothesis that afforestation provides better microclimate conditions for the city, the present study aimed to quantitatively compare the microclimate of streets with trees and the microclimate of streets without trees.

\section{MATERIAL AND METHODS}

The research was carried out in the city of Curitiba, located in the First Planalto of Paraná, at $934.6 \mathrm{~m}$ of average altitude. The city's ground zero is located at Praça Tiradentes, at latitude $25^{\circ} 25^{\prime} 40^{\prime \prime} \mathrm{S}$ and longitude $49^{\circ} 16^{\prime} 23^{\prime \prime} \mathrm{W}$. The climate is humid, mesothermal subtropical Cfb according to the Köppen climate classification, without a dry season, with cool summers and winters with frequent frosts (INSTITUTO DE PESQUISA E PLANEJAMENTO URBANO DE CURITIBA (IPPUC), 2011).

The climate of Curitiba presents a mild summer and moderate winter with some more rigorous days. Average temperatures are $19.7^{\circ} \mathrm{C}$ in summer and $13.4^{\circ} \mathrm{C}$ in winter. Rainfall has an annual average of $1,419.91 \mathrm{~mm}$ (IPPUC, 2011).

According to Bobrowski, Ferreira and Biondi (2011), the tree species most found in public streets in Curitiba are: H.chrysotrichus, T.tipu, L pacari, and P.rigida.

Three samples were established in Curitiba, named Alto da Rua XV, Hugo Lange and Bacacheri. Each sample presents a stretch of street with trees next to a stretch of street without trees (Figure 1).

The sample of Alto da Rua XV is formed by a section of Mal. Deodoro street without trees and Fernando Amaro street with Tipuana tipu. The urban configuration of both streets is similar. The stretch with trees features 32 large trees, distributed on both sides of the rolling road with $9 \mathrm{~m}$ tree spacing, providing $100 \%$ shading to the street. The individuals have the following characteristics: average height of $20 \mathrm{~m}$, Circumference at Breast Height $(\mathrm{CBH})$ of $200 \mathrm{~cm}$, average bifurcation height of $8 \mathrm{~m}$ and average canopy area of $200 \mathrm{~m}^{2}$.

The Hugo Lange sample is formed by a stretch of Augusto Stresser street without trees and Dr. Goulin street which is afforested with Handroanthus chrysotrichus. The urban configuration of both streets is also similar. The stretch with trees has 26 medium-sized trees, distributed on both sides of the rolling street with $7 \mathrm{~m}$ tree spacing, providing $47 \%$ shading to the street. The individuals have the following characteristics: average height of $8.5 \mathrm{~m}$, average $\mathrm{CBH}$ of $53 \mathrm{~cm}$, average bifurcation height of $3 \mathrm{~m}$, and average canopy area of $24 \mathrm{~m}^{2}$.

The Bacacheri sample is formed by a section of the Estados Unidos street without trees and another one with Lafoensia pacari and Parapiptadenia rigida. The section with trees has 9 trees of Lafoensia pacari (medium size) on the odd side, with spacing of $9 \mathrm{~m}$ and 12 tree of Parapiptadenia rigida (large size) on the even side, with spacing of $8 \mathrm{~m}$, which provides $74 \%$ of shading the street. Lafoensia pacari individuals have the following characteristics: average height of $8.5 \mathrm{~m}, \mathrm{CBH}$ of $86 \mathrm{~cm}$, average bifurcation height of $2 \mathrm{~m}$ and average canopy area of $20 \mathrm{~m}^{2}$. On the other hand, the Parapiptadenia rigida individuals have the following average characteristics: average height of $14 \mathrm{~m}, \mathrm{CBH}$ of $130 \mathrm{~cm}$, average height of bifurcation of $3.5 \mathrm{~m}$, and average area of canopy of 80 $\mathrm{m}^{2}$.

Two automatic meteorological ministations of the Kestre ${ }^{\circledR}$ brand were used to analyze the influence of street trees on the urban microclimate, remaining fixed on a tripod with a sensor table at $1.50 \mathrm{~m}$ in height. According to the manufacturer's description, Kestre ${ }^{\circledR}$ has precision in the temperature value to $\pm 1^{\circ} \mathrm{C}$, covering a range of use from $-29^{\circ} \mathrm{C}$ to $70^{\circ} \mathrm{C}$. The relative percentage values have precision of $\pm 3 \%$, covering a range detection range from 5 to $95 \%$ (without condensation). The wind speed has an accuracy of $3 \%$ of the reading value, between $0.6 \mathrm{~m} / \mathrm{s}$ and $40 \mathrm{~m} / \mathrm{s}$. 


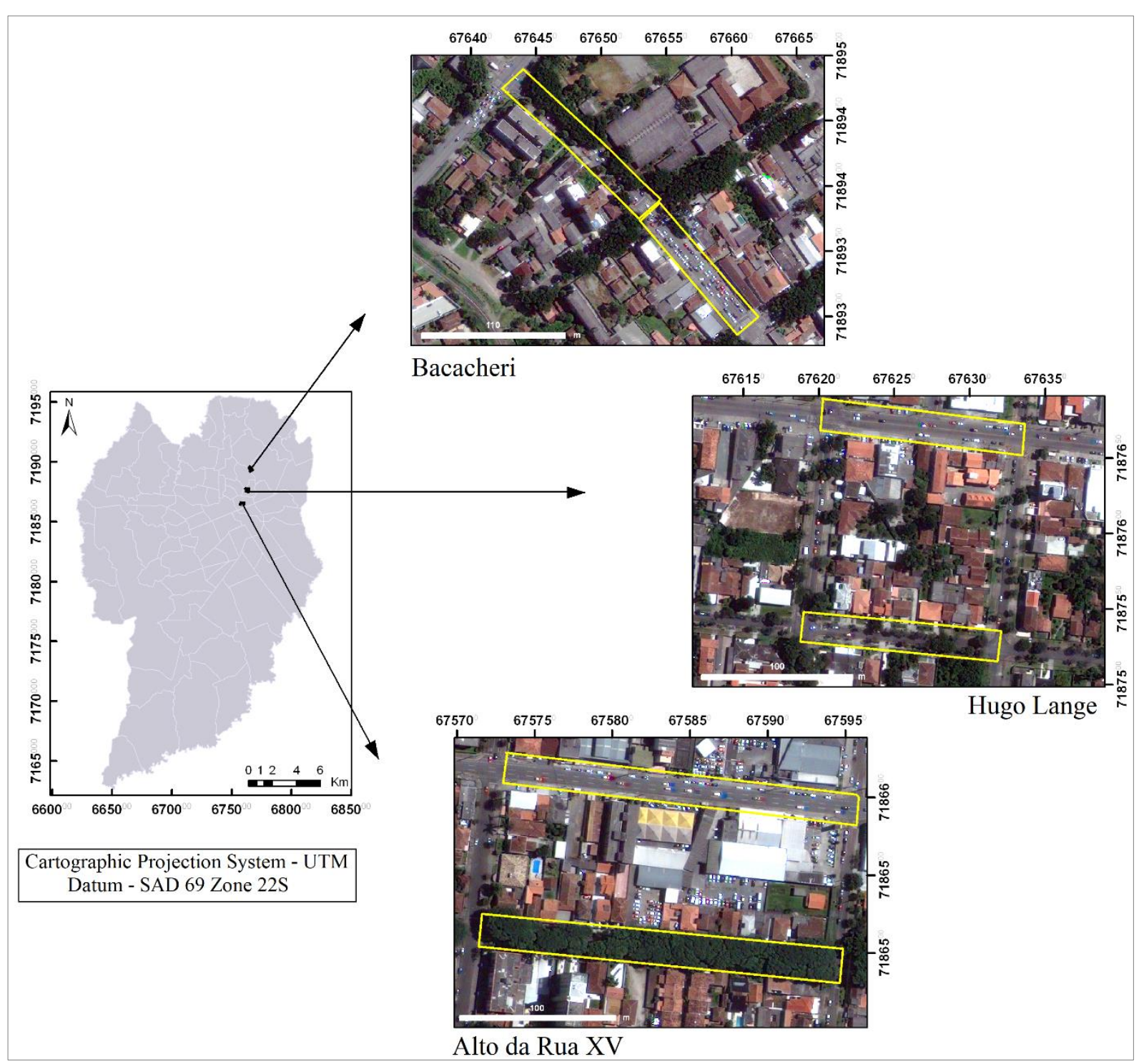

Figure 1. Location of the study samples in Curitiba-PR.

Figura 1. Localização das amostras de estudo na cidade de Curitiba-PR.

The equipment was positioned in the central portion of the square on the south sidewalk of the east-west streets (Mal. Deodoro, Fernando Amaro, Augusto Stresser and Dr. Goulin) and on the west sidewalk of the northsouth street (Estados Unidos) in order to reduce the interference caused by the apparent movement of the sun. The collection of meteorological variables was carried out through monitoring campaigns for security reasons and other possible human interference in which a team of researchers remained close to the devices throughout the collection period.

The influence of street trees on the urban microclimate was analyzed using the variables: air temperature $\left({ }^{\circ} \mathrm{C}\right)$, relative humidity $(\%)$ and wind speed $(\mathrm{m} / \mathrm{s})$. Meteorological variables for each sample were monitored on different days. Thus, one device remained on the street with trees and the other on the street without trees on each collection day. The procedure was repeated in the four seasons. As a way to better characterize the stations, the monitoring campaigns were adopted as a criterion in the central two weeks of each station (Table 1), but the daily weather condition (which cannot be controlled) was variable between open skies and clouds. Although only three days per season (three samples) were needed, two weeks were stipulated as a safety margin against possible unforeseen events such as rainy days, equipment failures and an insufficient number of researchers to go out into the field.

FLORESTA, Curitiba, PR, v. 50, n. 3, p. 1486 - 1493, jul/set 2020

Martini, A. et.al.

ISSN eletrônico 1982-4688

DOI: 10.5380/rf.v50 i3. 62194 
Table 1. Days, places and monitoring period in each season.

Tabela 1. Dias, locais e período de monitoramento em cada estação do ano.

\begin{tabular}{|c|c|c|c|}
\hline DAYS & PERIOD & SAMPLES & STREET \\
\hline \multicolumn{4}{|c|}{ WINTER 2011} \\
\hline $03 / 08$ & \multirow{3}{*}{$9: 00-15: 00$} & Alto da Rua XV & Mal. Deodoro/ Fernando Amaro \\
\hline $04 / 08$ & & Hugo Lange & Augusto Stresser/ Dr. Goulin \\
\hline $05 / 08$ & & Bacacheri & Estados Unidos \\
\hline \multicolumn{4}{|c|}{ SPRING 2011} \\
\hline $31 / 10$ & \multirow{3}{*}{$\begin{array}{c}\text { 10:00 - 16:00 } \\
\text { (daylight saving) }\end{array}$} & Alto da Rua XV & Mal. Deodoro/ Fernando Amaro \\
\hline $03 / 11$ & & Bacacheri & Estados Unidos \\
\hline $04 / 11$ & & Hugo Lange & Augusto Stresser/ Dr. Goulin \\
\hline \multicolumn{4}{|c|}{ SUMMER 2012} \\
\hline $30 / 01$ & \multirow{3}{*}{$\begin{array}{c}\text { 10:00 - 16:00 } \\
\text { (daylight saving) }\end{array}$} & Hugo Lange & Augusto Stresser/ Dr. Goulin \\
\hline $31 / 01$ & & Alto da Rua XV & Mal. Deodoro/ Fernando Amaro \\
\hline $02 / 02$ & & Bacacheri & Estados Unidos \\
\hline \multicolumn{4}{|c|}{ AUTUMN 2012} \\
\hline $03 / 05$ & & Alto da Rua XV & Mal. Deodoro/ Fernando Amaro \\
\hline $07 / 05$ & $9: 00-15: 00$ & Bacacheri & Estados Unidos \\
\hline $11 / 05$ & & Hugo Lange & Augusto Stresser/ Dr. Goulin \\
\hline
\end{tabular}

Monitoring was carried out in the winter and spring of 2011 and in the summer and autumn of 2012, and the data collection period was from 9 am to $3 \mathrm{pm}$ (Brasília time), being corrected to 10 am and 4 pm in summer time with a 1-minute monitoring interval, which generated a set of 360 data per day on each street.

For a general analysis, all values recorded every minute in the streets with trees (4320 data) were compared with all values found in the streets without trees (4320 data) using the Student's t-test at $99 \%$ significance to assess possible differences in street weather conditions. Next, a more detailed analysis was carried out in which the values found in the streets with trees (360 data) and without trees (360 data) were evaluated separately for each day of collection using the Student's t-test (99\% significance level). An analysis of variance was applied (ANOVA) in both analyzes before applying the means comparison tests.

\section{RESULTS}

The streets with trees had a different microclimate condition than the streets without trees, which proves that street trees have a significant influence on the meteorological variables in the city's microclimate. The streets without trees generally had higher values of temperature and wind speed and lower values of relative humidity (Table 2).

Table 2. Average microclimatic variables on the street with and without trees and statistical analysis (t-test). Tabela 2. Média das variáveis microclimáticas nas ruas com e sem arborização e análise estatística (teste t).

\begin{tabular}{cccc}
\hline \multirow{2}{*}{ Street Trees } & $\begin{array}{c}\text { Temperature } \\
\left({ }^{\circ} \mathbf{C}\right)\end{array}$ & $\begin{array}{c}\text { Relative } \\
\text { Humidity }(\%)\end{array}$ & Wind Speed (m/s) \\
\hline Without & 20.9 & 50.9 & 0.70 \\
With & 19.2 & 56.8 & 0.66 \\
\hline t-test & $12.43^{* *}$ & $19.61^{* *}$ & $5.10^{* *}$ \\
\hline
\end{tabular}

Note: ** Significant at $1 \%$ probability by the Student's t-test.

It is observed that the statistical analysis applied to the temperature values showed a significant difference between the averages of the streets with trees $\left(19.2^{\circ} \mathrm{C}\right)$ and without trees $\left(20.9^{\circ} \mathrm{C}\right)$. The average values of relative humidity of the streets with trees $(56.8 \%)$ were also different from those found in streets without trees $(50.9 \%)$. This fact was repeated for the variable wind speed, where the average of the streets with trees was $0.66 \mathrm{~m} / \mathrm{s}$ and the streets without trees with $0.70 \mathrm{~m} / \mathrm{s}$. Thus, it was possible to statistically prove the street trees influence the local microclimate. 
The average between the values of the three samples analyzed in each season of the year revealed that the temperature of a streets with trees is $1.7^{\circ} \mathrm{C}$ lower than that of a street without trees, the relative humidity is $6.9 \%$ higher and the wind speed is $0.04 \mathrm{~m} / \mathrm{s}$ less.

The effect that street trees have on the microclimate can be demonstrated in general way (Table 2). However, this study was carried out in the four seasons and using different species which requires a more detailed analysis. Therefore, some specificities are observed when separately analyzing the values found in streets with trees and without trees for each day of collection (Table 3).

Table 3. Average microclimatic variables and statistical analysis (t-test) among the street with and without trees in each sample and season.

Tabela 3. Média das variáveis microclimáticas e análise estatística (teste t) entre a rua com e sem arborização em cada amostra e estação do ano.

\begin{tabular}{|c|c|c|c|c|c|c|c|c|c|}
\hline \multirow{2}{*}{ Season } & \multicolumn{3}{|c|}{ Alto da Rua XV } & \multicolumn{3}{|c|}{ Hugo Lange } & \multicolumn{3}{|c|}{ Bacacheri } \\
\hline & without & with & t-test & without & with & t-test & without & with & t-test \\
\hline \multicolumn{10}{|c|}{ Temperature $\left({ }^{\circ} \mathrm{C}\right)$} \\
\hline Winter & 10.1 & 9.7 & $2.48 *$ & 13.8 & 13.8 & $0.10^{\mathrm{ns}}$ & 16.33 & 13.02 & $12.36 * *$ \\
\hline Spring & 18.5 & 16.2 & $24.97 * *$ & 21.5 & 21.7 & $1.19^{\mathrm{ns}}$ & 18.56 & 16.28 & $25.10 * *$ \\
\hline Summer & 28.7 & 25.0 & $26.37 * *$ & 30.5 & 28.7 & $12.44 * *$ & 30.32 & 28.25 & $13.51 * *$ \\
\hline Autumn & 19.8 & 17.7 & $17.37 * *$ & 23.8 & 21.5 & $18.37 * *$ & 18.73 & 18.50 & $3.30 * *$ \\
\hline \multicolumn{10}{|c|}{ Relative Humidity (\%) } \\
\hline Winter & 61.2 & 65.4 & $7.89 * *$ & 33.4 & 34.5 & $3.00 * *$ & 53.1 & 64.5 & $14.33 * *$ \\
\hline Spring & 53.8 & 64.3 & $41.96 * *$ & 46.9 & 46.1 & $2.22 *$ & 51.7 & 61.1 & $35.17 * *$ \\
\hline Summer & 38.7 & 46.2 & $30.97 * *$ & 34.7 & 40.1 & $14.21 * *$ & 42.2 & 46.3 & $6.11 * *$ \\
\hline Autumn & 68.7 & 73.7 & $10.10 * *$ & 52.2 & 61.9 & $22.26 * *$ & 74.2 & 77.6 & $15.94 * *$ \\
\hline \multicolumn{10}{|c|}{ Wind Speed $(\mathrm{m} / \mathrm{s})$} \\
\hline Winter & 0.8 & 0.7 & $5.16 * *$ & 1.0 & 0.4 & $17.93 * *$ & 0.8 & 1.0 & $6.41 * *$ \\
\hline Spring & 0.7 & 1.0 & $8.37 * *$ & 1.2 & 0.6 & $15.38 * *$ & 0.7 & 1.0 & $9.15 * *$ \\
\hline Summer & 0.6 & 0.6 & $1.11^{\mathrm{ns}}$ & 0.2 & 0.2 & $1.68^{\mathrm{ns}}$ & 0.8 & 0.7 & $0.23 * *$ \\
\hline Autumn & 0.4 & 0.8 & $13.51 * *$ & 0.1 & 0.7 & $28.20 * *$ & 1.1 & 0.2 & $29.13 * *$ \\
\hline
\end{tabular}

Note: (ns) Not significant; $(*)$ Significant at 5\% probability; $(* *)$ Significant at $1 \%$ probability by the Student's t-test.

The statistical analysis performed showed a significant difference between the average temperature of the streets with and without trees in all seasons of the year in the Alto da Rua XV and Bacacheri samples. This occurred even when this difference was very small, such as in the winter season in the Alto da Rua XV sample $\left(0.4^{\circ} \mathrm{C}\right)$ and in the autumn in the Bacacheri sample $\left(0.2^{\circ} \mathrm{C}\right)$. There was no statistical difference between the average street temperature with and without trees only in the Hugo Lange sample in the winter and spring seasons, while the average temperature of the two streets were equal in winter $\left(13.8^{\circ} \mathrm{C}\right)$, and the spring was the only occasion where the average of the street with trees $\left(21.7^{\circ} \mathrm{C}\right)$ was slightly higher than the average of the street without trees $\left(21.5^{\circ} \mathrm{C}\right)$.

The statistical analysis performed showed a significant difference between the average of the street without trees and the average of the street with trees for the relative humidity values in all seasons and in all samples. There was no statistical difference between the average of the street without trees and the average of the street with trees for the wind speed values in the summer season for the samples Alto da Rua XV and Hugo Lange, where the values were equal between the streets.

\section{DISCUSSION}

The microclimate of streets with trees had different conditions than streets without trees, showing higher temperature and lower relative humidity values. These results were also found by other authors in similar research who sought to assess the influence of green areas on the urban microclimate.

In a park in Nagoya (Japan), Hamada and Ohta (2010) found temperature differences of $1.9^{\circ} \mathrm{C}$ in the summer and $-0.3^{\circ} \mathrm{C}$ in the winter. In Manchester (England) in the summer season, it was found that although the shade of a tree only reduces the air temperatures by 1 or $2^{\circ} \mathrm{C}$, the perceived temperatures are significantly lower in the shade on hot and sunny days (ARMSON et al., 2012).

FLORESTA, Curitiba, PR, v. 50, n. 3, p. 1486 - 1493, jul/set 2020

Martini, A. et.al.

ISSN eletrônico 1982-4688 
In the city of Curitiba in an area with Mixed Rainforest, Soldera et al. (2014) found that the external temperature was on average $3.9^{\circ} \mathrm{C}$ higher and the relative humidity was $19.5 \%$ lower than in the interior of the forest. In Bosque Gutierrez, another remnant of Mixed Ombrophilous Forest, the temperature was $4.4^{\circ} \mathrm{C}$ lower and the relative humidity was 17.8 units higher (SILVA et al., 2014). In a planned green area, known as Praça Alfredo Andersen, the average temperature was $1.4{ }^{\circ} \mathrm{C}$ lower under the shade of trees than in the surroundings, and the relative humidity was 5 units higher (VIEZZER et al., 2015).

The authors in all of these works quantitatively verified the influence that vegetation has on the microclimate. However, it is noteworthy that studies specifically referring to street trees in Brazil are non-existent, so the real influence that planting trees on public roads has on the microclimate of a city is still unknown. Bearing in mind that the mentioned studies refer to large green areas existing in cities, it is possible to affirm that the values found in the present research are extremely important, since the influence of street trees on the microclimate was similar to that verified in green areas.

According to most of the works mentioned, the decrease in temperature that a green area provides was from 1 to $4^{\circ} \mathrm{C}$, whereas the decrease caused by the street trees in this study was on average $1.7^{\circ} \mathrm{C}$, reaching up to $3.7^{\circ} \mathrm{C}$. With regard to relative humidity, the studies showed values around 5 and 15 units higher in green areas. In the present study, it was found that street trees provide an average increase of $6.9 \%$ in relative humidity, reaching up to $11.4 \%$.

A similar study was found in Dresden (Germany), where the air temperature in streets with trees was 0.9 to $2.6^{\circ} \mathrm{C}$ lower than in an environment without vegetation and the relative humidity was higher, ranging from 0.6 to 6.4 units (GILLNER et al., 2015).

The results found for the wind speed do not allow to affirm a trend, although the average value indicates that the streets with trees provides lower wind speed values $(0.04 \mathrm{~m} / \mathrm{s})$, even though this value was small. In addition, variations are observed when the values are analyzed separately on each collection day.

Wind speed is a little used variable in studies which address the influence of vegetation on the urban microclimate, as winds in cities are influenced by different urban structures and equipment, and their analysis is difficult to understand. However, the results found in the summer season stand out, where it was found that the vegetation did not provide a barrier to the passage of winds on the studied streets, so in that season where temperatures are higher, the presence of wind created a more pleasant microclimate.

The benefits provided by street trees related to the microclimate found in this study were evident, although Mahmoud (2011) stated that isolated trees distributed with wide spacing (as is the typical case of an urban street) do not have a significant effect on cooling the air; however was possible to verify that if planted close together in this alignment, this effect does not occur. Many studies suggest that the use of small clusters of trees (parks, forests and squares) is more efficient for cities (SHASHUA-BAR et al., 2010). Therefore, it was proved with this study that the linear planting of grouped trees on the streets is a promising alternative for improving the microclimate of a city.

Even the analysis carried out separately for each collection day demonstrated the positive and significant influence that street trees have on the microclimate. It is known that the absorption of radiant energy by the chloroplasts in the photosynthesis process is a prerequisite for its occurrence (LARCHER, 2006). It is estimated that between 60 and $75 \%$ of the solar energy on vegetation is consumed in physiological processes, as plants do not store heat in their cells (BERNATZKY, 1980). In this sense, the barrier provided by the canopy of the treetops prevents penetration of most of the solar radiation during the day. This lesser amount of solar radiation incidence implies in less soil heating and consequently less long-wave radiation emission and less air heating in the space between the soil and the treetops (HERNANDES et al., 2002). Thus, there was clearly a greater microclimate benefit in the sample with a higher percentage of shading offered by the treetops and a lower benefit in the lower proportion of shading.

Information regarding the entry of radiation into the wooded environment can help explain the unexpected results found in the Hugo Lange sample, where the street is afforested with the Handroanthus chrysotrichus species. In addition to this species having a thin crown, the individuals were planted with greater spacing between trees, making the crowns isolated. Thus, the streets with trees had little restriction on radiation entering into the environment, interfering little in the energy balance, and thereby resembling the street without trees, especially in stations where there are marked changes in its phenological stage.

Finally, to understand how vegetation influences the microclimate, Oke (1989) stated that vegetation provides cooling in constructed areas using two means: the shading generated by vegetation, which reduces the conversion of radiant energy into sensitive heat and consequently reduces the surface temperatures of shaded objects; and also by evapotranspiration on the leaf surface, which cools the leaf and the surrounding air due to the latent heat exchange.

FLORESTA, Curitiba, PR, v. 50, n. 3, p. 1486 - 1493, jul/set 2020. 


\section{CONCLUSÃO}

- It is concluded that the microclimate of a street with trees is milder than that of a street without trees, with the difference between the studied environments (with and without trees) being statistically proven.

- The streets with trees showed lower temperature (on average $1.7^{\circ} \mathrm{C}$ ) and higher relative humidity (on average $6.9 \%$ ) Values. It was not possible to determine a trend regarding wind speed.

- The results found emphasize the importance of street trees for cities, as the decrease in temperature and the increase in relative humidity provided by this vegetation are similar to the values found in green areas. In addition, it is worth highlighting the importance that a proper choice of species is made for each specific location, considering the seasonality of the plant and other particularities of the environment in order to accentuate the benefits provided by urban forests.

\section{ACKNOWLEDGMENTS}

To the Fundação Araucária for Scientific Support and Technological Development of Paraná for financing the purchase of equipment.

\section{REFERENCES}

ARMSON, D.; STRINGER, P.; ENNOS, A. R. The effect of tree shade and grass on surface and globe temperatures in an urban area. Urban Forestry \& Urban Greening, Davis, v. 11, p. 245 - 255, 2012.

BENATTI, D. P.; TONELLO, K. C.; ADRIANO JÚNIOR, F. C.; SILVA, J. M. S.; OLIVEIRA, I. R.; ROLIM, E. N.; FERRAZ, D. L. Inventário arbóreo-urbano do município de Salto de Pirapora, SP. Revista Árvore, Viçosa, v. 36, n. 5, p. 887 - 894, 2012.

BERNATZKY, A. Tree ecology and preservation. 2. ed. Amsterdam: Elsevier, 1980. 357 p.

BOBROWSKI, R.; FERREIRA, R. L. C.; BIONDI, D. Descrição Fitossociológica da Arborização de Ruas por Meio de Diferentes Formas de Expressão da Dominância e da Densidade. Ciência Florestal, Santa Maria, v. 26, n. 4, p. 1167 - 1178, 2016.

BOBROWSKI, R.; BIONDI, D. Distribuição e dinâmica da área de copa na arborização de ruas de Curitiba, Paraná, Brasil, no Período de 1984-2010. Revista Árvore, Viçosa-MG, v. 36, n. 4, p. 625 - 635, 2012.

CHANG, C.; LI, M. Effects of urban parks on the local urban thermal environment. Urban Forestry \& Urban Greening, Amsterdam, v. 13, p. 672-681, 2014.

DONOVAN, G. H.; BUTRY, D. T. Trees in the city: valuing street trees in Portland, Oregon. Landscape and Urban Planning, Amsterdam, v. 94, n. 2, p. 77-83, 2010.

GILLNER, S.; VOGT, J.; THARANG, A.; DETTMANN, S.; ROLOFF, A. Role of street trees in mitigating effects of heat and drought at highly sealed urban sites. Landscape and Urban Planning, Amsterdam, v. 143, p. 33-42, 2015.

HAMADA, S.; OHTA, T. Seasonal variations in the cooling effect of urban green areas on surrounding urban areas. Urban Forestry \& Urban Greening, Amsterdam, v. 9, p. 15-24, 2010.

HERNANDES, J. L.; PEDRO-JUNIOR, M. J.; BARDIN, L. Diferenças estacionais entre variáveis microclimáticas para ambientes de interior de mata, vinhedo e posto meteorológico em Jundiaí (SP). Bragantia, Campinas, v. 61, n. 2, p. 169 - 180, 2002.

HUANG, L.; LI, J.; ZHAO, D.; ZHU, J. A fieldwork study on the diurnal changes of urbanmicroclimate in four types of ground cover and urban heat island of Nanjing, China. Building and Environment, Oxford, v. 43, p. 7 $17,2008$.

INSTITUTO DE PESQUISA E PLANEJAMENTO URBANO DE CURITIBA (IPPUC). Desenvolvimento sustentável: indicadores de sustentabilidade de Curitiba - 2010. Curitiba: IPPUC, 2011. 77 p.

JIANG, B.; LARSEN, L.; DEAL, B.; SULLIVAN, W. C. A dose-response curve describing the relationship between tree cover density and landscape preference. Landscape and Urban Planning, Amsterdam, v. 139, p. $16-25,2015$.

JIM, C.Y.; LO, A. Y.; BYRNE, J. A. Charting the green and climate-adaptive city. Landscape and Urban Planning, Amsterdam, v. 138, p. 51-53, 2015.

FLORESTA, Curitiba, PR, v. 50, n. 3, p. 1486 - 1493, jul/set 2020.

Martini, A. et.al.

ISSN eletrônico 1982-4688 
LARCHER, W. Ecologia vegetal. São Carlos: RiMa, 2006. 532 p.

MAHMOUD, A. H. A. Analysis of the microclimatic and human comfort conditions in an urban park in hot and arid regions. Building and Environment, Oxford, v. 46, p. 2641 - 2656, 2011.

MARTINS, L. F. V.; ANDRADE, H. H. B. de; HANISCH, R. F.; DE ANGELIS, B. L. D.; CAXAMBU, M. G. Análise da compatibilidade da arborização viária com o ambiente construído na cidade de Luiziana, Paraná, Brasil. Revista da Sciedade Brasileira de Arborização Urbana, Piracicaba, v. 6, n. 3, p. 103 - 127, 2011.

OKE, T. R. The micrometerology of the urban forest. Phil. Trans. R. Soc. Lond. B., Great Britain, v. 324, p. 335 - 349, 1989.

SHASHUA-BAR, L.; TSIROS, I. X.; HOFFMAN, M. E. A modelling study for evaluating passive cooling scenarios in urban streets with trees. Case study: Athens, Greece. Building and Environment, Oxford, v. 45, p. 2798 - 2807, 2010.

SILVA, D. A.; BIONDI, D.; MARTINI, A.; VIEZZER, J. Influência Microclimática do Bosque Gutierrez na Cidade de Curitiba-PR, Brasil. Enciclopédia Biosfera, Goiânia, v. 10, n. 19, p. 2327-2338, 2014.

SOLDERA, C.; BIONDI, D.; MARTINI, A. Microclima e Conforto Térmico na Trilha do Capão do Tigre - Espaço com Atividades de Educação Ambiental. Enciclopédia Biosfera, Goiânia, v.10, n.19, p. 2348-2359, 2014.

VIEZZER, J.; BIONDI, D.; MARTINI, A.; SILVA, D. A. da. O benefício microclimático proporcionado pela Praça Alfredo Andersen na cidade de Curitiba-PR. Ciência e Natura, Santa Maria, v. 37, Edição Especial SIC, p. 138-143, 2015.

VOLPE-FILIK, A.; SILVA, L. F. da; LIMA; A. M. L. P. Avaliação da arborização de ruas do bairro São Dimas na cidade de Piracicaba/SP através de parâmetros qualitativos. Revista da Sociedade Brasileira de Arborização Urbana, Piracicaba, v. 2, n. 1, p. 34 - 43, 2007.

YU, C.; HIEN, W. N. Thermal benefits of city parks. Energy and Buildings, Lausanne, v. 38, p. 105 - 120, 2006. 